\title{
Viral Marketing Strategies and Customer Buying Behavioural Intentions at Retail Store in Johannesburg
}

\author{
Tarisai Fritz Rukuni (Corresponding author) \\ Dept. of Commerce, CTI Education Group \\ 9 Concorde Street, Bedfordview, Johannesburg, South Africa \\ Tel: 27-73-418-1426Ｅ-mail: tarisair@cti.ac.za
}

\begin{abstract}
Grant Shaw
Dept. of Commerce, CTI Education Group

9 Concorde Street, Bedfordview, Johannesburg, South Africa

Tel: 27-60-528-7108Ｅ-mail: grantshaw15@gmail.com

Yumesan Chetty

Dept. of Commerce, CTI Education Group

9 Concorde Street Bedfordview, Johannesburg, South Africa

Tel: 27-81-024-9945Ｅ-mail: yumesan.chetty@gmail.com
\end{abstract}

Petunia Kgama

Dept. of Commerce, CTI Education Group

9 Concorde Street Bedfordview, Johannesburg, South Africa

Tel: 27-78-170-0270Ｅ-mail: BE2013-0366@educationgroup.co.za

Pebetse Kekana

Dept. of Commerce, CTI Education Group

9 Concorde Street Bedfordview, Johannesburg, South Africa

Tel: 27-79-194-1349Ｅ-mail: pebetsi15@gmail.com 


\author{
Kyle Rogers \\ Dept. of Commerce, CTI Education Group \\ 9 Concorde Street Bedfordview, Johannesburg, South Africa \\ Tel: 27-79-500-7960Ｅ-mail: kylektm136@gmail.com
}

Received: Jan. 26, 2017 Accepted: Jan. 30, 2017 Published: May 15, 2017

doi:10.5296/bms.v8i1.10676 URL: https://doi.org/10.5296/bms.v8i1.10676

\begin{abstract}
The advent of viral marketing in South Africa has been supply focused and retail operators did not realise the importance of including customers' views during the creation of viral marketing strategies. Failure of these stores to incorporate customers' views during the crafting of viral marketing strategies, leads to ineffective viral advertising campaigns, product boycott and decrease in sales. Given the constant change in consumer needs and expectations, an understanding of customers' opinions towards viral marketing strategies adopted by a retail store in Johannesburg, has become a remarkable strategy to gain a competitive advantage. For that reason, it is important for retail stores to understand their customers' perceptions of viral marketing strategies. Based on this background, the purpose of this study was twofold: i) to assess customers' perceptions of viral marketing strategies, and ii) investigate how viral marketing strategies influence customers' buying behavioural intentions. A descriptive case study approach was conducted. A quantitative methodology, through which a structured questionnaire was also used to collect data from a sample of at least 172 customers at outlets of a retail store in Johannesburg. SPSS was utilised to conduct descriptive and multivariate analyses including factor analysis, correlations, and regression analyses. Results indicated that customers had negative perceptions towards viral marketing strategies tested. In addition, all the four predictor variables (informativeness, entertainment, irritation and source credibility) were found to be positively correlated to customer buying behavioural intentions. Recommendations and gaps for further research are also presented within the context of viral marketing theory.
\end{abstract}

Keywords: Viral marketing, Informativeness, Entertainment, irritation, Credibility, Buying intentions 


\section{Introduction}

In recent years, viral marketing has received the attention of marketing programmes in most retail organisations across the world (Eckler \& Bolls, 2011). However, its adoption especially by big retail stores in South Africa, has not been customer-centred, instead it has focused mostly on the supply side. According to Zernigah and Sohail (2012), Bampo, Ewing, Mather, Stewart and Wallace (2008) and Chiu, Hsieh, Kao and Lee (2007), failure of these stores to incorporate customers' views during the crafting of viral marketing strategies, has led to ineffective advertising campaigns, product boycott and decrease in sales. Given the constant change in consumer needs and expectations, an understanding of customers' opinions towards viral marketing strategies by retail stores becomes a remarkable strategy to gain competitive advantage.

Extant literature (Zernigah \& Sohail, 2012) shows that most retail stores in developing countries including South Africa, have not yet realised the importance of incorporating the voice of customers in crafting viral marketing strategies. Furthermore, the perception of customers towards viral marketing is hardly considered an issue of importance by big retail stores in SA (Business Tech, 2015). The literature also tends to ignore this subject, which can be considered a gap in the body of knowledge. It was, therefore, an opportunity to conduct this study which was determined at assessing customers' perceptions of viral marketing strategies and how viral marketing strategies influence customers' buying behavioural intentions.

\subsection{Social Media and the Rise of Viral Marketing in South Africa}

Gaining popularity of social media has opened opportunity for retailers in many nations (Zernigah \& Sohail, 2012), with the inclusion of South Africa. Studies have been done to understand the penetration of social media in SA and it was realised that the society responded immensely towards the innovation. According to World Wide Worx (2016), Instagram has become widely used by South Africans while Facebook is second in topping the charts.

The study (World Wide Worx, 2016) showed rapid growth in the use of social media in South Africa. Remarkable growth has been seen in Facebook, Twitter, YouTube and Instagram, recording an increase of 8 per cent, 12 per cent, 15 per cent and 133 per cent respectively (World Wide Worx, 2016). Social media has been found to be quite influential in recent years within the South African market.

On the other hand, social media apps were found to be at a rise in South Africa. Free downloads from major app stores such as Google Play, Apple App Store and Windows Store, surfaced. Major app downloads have been on WhatsApp and Facebook by most users of smartphones in South Africa. These developments have been crucial in triggering viral marketing use by most retailers in South Africa. It is upon this background that this current study was carried out so as to understand the perception of customers towards viral marketing strategies at the retail outlets in Johannesburg South Africa.

\subsubsection{Viral Marketing}


Viral marketing is defined as the passing of an organisation's content from one individual to another through the use of social network. It is therefore defined by Zernigah and Sohail (2012) as "electronic word of mouth". On the other hand Palka, Pousttchi and Wiedemann (2009) defined it as "... a method of marketing that infects customers with an advertising message which passes from one customer to another like a rampant flu." All the definitions show that viral marketing permits a quick flow of message within a social network of customers using social media.

\subsubsection{Buying Behavioural Intentions}

Buying behavioural intentions refer to the possible purchasing action taken by a consumer upon exposure to a stimuli, for example a viral marketing message (Robbins, Judge, Odendaal \& Roodt, 2016). It is extensively documented in literature that viral marketing strategies are pivotal towards consumer behaviour (i.e. buying intention, product advocacy, referral) (Zernigah \& Sohail, 2012). Customer buying behavioural intentions are important in this study, since it is regarded a measure of the effectiveness of viral marketing strategies used by the retail store.

\section{Medium Used in Viral Marketing}

According to Akrimi and Khemakhem (2012) and Goldsmith and Horowitz (2006), mediums used in viral marketing include email, instant chats, blogs and many others. Communicating on a preferred client level ensures maximum profitability. Therefore, email is used to interact personally with clients. Instant chat rooms are utilised to ensure speedy interaction for enquires. Blogs allow clients to communicate to businesses and see what they are about. Most effort was on putting out the content but this has changed in recent times. Ultimately, clients, opinions matter and their insights need to be valued. A happy customer brings profitability once their opinions are considered.

As already mentioned, marketing mediums are endless, these include social media, for example Facebook and WhatsApp. These platforms are used on a daily basis and are perfect avenues to promote a company. Videos, games, and even software are avenues to be utilised for ads that viewers constantly use while noticing different brands (Gangadhardatla, 2008).

\section{Benefits of Viral Marketing}

The significance of viral marketing has been widely documented by specialists in the field (Dawar \& Dawar, 2015; Shashikala \& Mahapatro, 2015; Zernigah \& Sohail, 2012; Pelau \& Zegreanu, 2010; Haghirian, Madlberger \& Tanuskova, 2005). Benefits of viral marketing are cost effectiveness, interactive promotional methods, convenient medium, ability to reach a large audience, deliver personalised messages, high speed of message transmission and a minimum level of effort is needed to pass the message.

Viral marketing is one of the methods that are found to be cost effective. This is supported by Zernigah and Sohail (2012) and Woerndl, Papagiannidis, Bourlakis and Li (2008) who raised 
that viral marketing contributes to cost effective avenues. Thus, retailers are able to minimize the cost structure while influencing positively on the profit levels of the organization.

The use of viral marketing is facilitated through social media. Social media has an interactive nature that allows coercion of friends, family members and people within the social circle. As such, Haghirian, Madlberger and Tanuskova (2005) support the fact that viral marketing is hugely used due to interaction that takes between customers.

For the purpose of convenience, viral marketing was found to be useful. Thus, retailers are able to interact with customers at any point in time. According to Dawar and Dawar (2015), retailers can conveniently interact with customers without difficulties. It is also possible to reach a large audience with the use of viral marketing (Zernigah \& Sohail, 2012). A large audience is reached at high speed due to the latest technology in social media. Quite important also is the fact that messages sent to audiences can be personalised according to their needs.

Considering all the benefits explored in this section of the study, an understanding of customers' perception towards viral marketing strategies used by the retailer, is vital. It is an important component since it will contribute to further improve viral marketing strategic programmes of retail operations.

\section{Viral Marketing Strategies}

Authors (Dawar \& Dawar, 2015; Shashikala \& Mahapatro, 2015; Zernigah \& Sohail, 2012) have put forward different forms of strategies used in viral marketing. Literature have shown that viral marketing strategies include the level of information, level of entertainment, irritation level and source credibility.

\subsection{Informativeness}

Informativeness refers to the amount of information contained in a viral message, for example, the viral marketing message. According to Zernigah and Sohail (2012) and Saadeghvaziri and Hosseini (2011), the informativeness of an advertisement is crucial in determining its effects. The aspect of informativeness was also seen to yield benefits to retailers since it creates a positive behavioural intention. Authors such as Tsang, Ho and Liang (2004) and Haghirian et al. (2005), suggested that consumers need to receive information that is up to date, relevant and useful to their needs, hence the importance of informativeness. Thus, making informativeness a crucial construct of the study.

\subsection{Entertainment}

Entertainment refers to the level of enjoyment that can be provided by a stimuli, for example an advert through humour and fun. Entertainment provided by a viral message has been found to be an important strategy in creating a successful viral marketing technique (Shashikala \& Mahapatro, 2015; Saadeghvaziri \& Hosseini, 2011; Tsang et al., 2004). Studies have shown 
that consumers prefer viral messages that provide entertainment. It is for this reason that the viral marketing strategy was tested in this study for its level of entertainment.

\subsection{Irritation}

Irritation refers to the level of annoyance that is created by a stimulus in viral marketing strategy. According to Muzaffar and Kamran (2011), irritation of viral marketing needs to be taken into consideration. Customers develop a negative attitude towards messages that are irritating, whereas non-irritating messages would receive a fair share of circulation. It is therefore important for this study to test the level of irritation on viral marketing strategies utilised at the retail store in Johannesburg.

\subsection{Source credibility}

Source credibility is the level of respect that is given to the originator of the message. The credibility of the source of the message plays a significant role in marketing viral marketing strategy effectively. According to Ghane, Shokrizadeh, Omidvar and Comyab (2014), the credibility of the message depends on a number of factors that include the organisation credibility. Building a great reputation for the organisation is essential, since it has a positive effect towards the viral message circulated by the organisation.

Among many other strategies, informativeness, entertainment, irritation and source credibility are strategies that were chosen for this present study that seeks to understand customers' perception of viral marketing strategies utilised at a retail store in Johannesburg and the impact these strategies have on customers' buying behavioural intentions. The following section looks at previous empirical studies and identification of research gaps.

\section{Empirical Studies and Development of a Research Gap}

In the past, similar viral marketing studies were conducted by various authors (Shashikala \& Mahapatro, 2015; Zernigah \& Sohail, 2012; Muzzaffar \& Karan, 2011; Blanco, Blasco \& Azorin, 2010; Fagerstrom \& Ghinea, 2010; Reyck \& Degraeve, 2003) to understand the impact of informativeness, entertainment, source credibility and irritation as strategies for viral marketing.

Zernigah and Sohail (2012)'s study in Pakistan on a sample of 216 respondents found that viral marketing strategies such as informativeness, entertainment, and source credibility are positively related to customers' attitude towards viral marketing strategy. Since these findings were for Pakistan, it is important to carry out a study within the South African context and understand consumers' perception on similar variables.

Zernigah and Sohail (2012)'s study also found that informativeness and source credibility were found to be the most important aspects in viral marketing. On the other hand, Shashikala and Mahapatro (2015), Muzaffar and Kamran (2011) and Reyck and Degraeve (2003) found entertainment to be the most important aspect that leads to customers' positive attitude towards 


\section{Macrothink}

Business Management and Strategy

ISSN 2157-6068

2017, Vol. 8, No. 1

viral marketing. Given these contradicting findings, it is therefore important to undertake this current study to find out the most important strategy in viral marketing strategies.

A study carried out by Blanco et al. (2010) found that customers perceived low informativeness on the mobile advertisement. It is also important to undertake this study which seeks to assess the opinions of customers in the South African context. Empirical studies have opened gaps for further studies regarding viral marketing strategies. The next section will highlight the research problem and the research question.

\section{The Problem Statement, Research Question and Study Objectives}

\subsection{The Problem Statement}

As previously noted, perceptions of customers towards the development of viral marketing strategies are rarely considered an issue of importance by SA retail store authorities, neither are they regarded as a matter of survival by these stores (Zernigah $\&$ Sohail, 2012). But, the growth of unattended customer viral marketing needs and expectations threatens the relationship with customers, leading to customer dissatisfaction and a possible drop in revenue. For that reason, it is important for retail stores to understand their customers' perceptions of viral marketing strategies and how they influence consumer buying behavioural intentions.

\subsection{Research Question}

To what extent do the perceptions of viral marketing strategies influence buying behavioural intentions among customers at a retail store in Johannesburg?

\subsection{Objectives of the Study}

6.3.1 To assess customers' perceptions of viral marketing strategies.

6.3.2 To investigate how viral marketing strategies influence customers' buying behavioural intentions.

\section{The Conceptual Model}

The conceptual theoretical model given in Figure 1. is grounded on the viral marketing theory (impact of viral marketing strategies). It conceptualise the relationship between factors influencing viral marketing strategies and customer buying intentions. Customer buying behavioural intentions are the dependent variables while viral marketing strategies (informativeness, entertainment, irritation and source credibility) are independent variables. The model tested is illustrated next: 


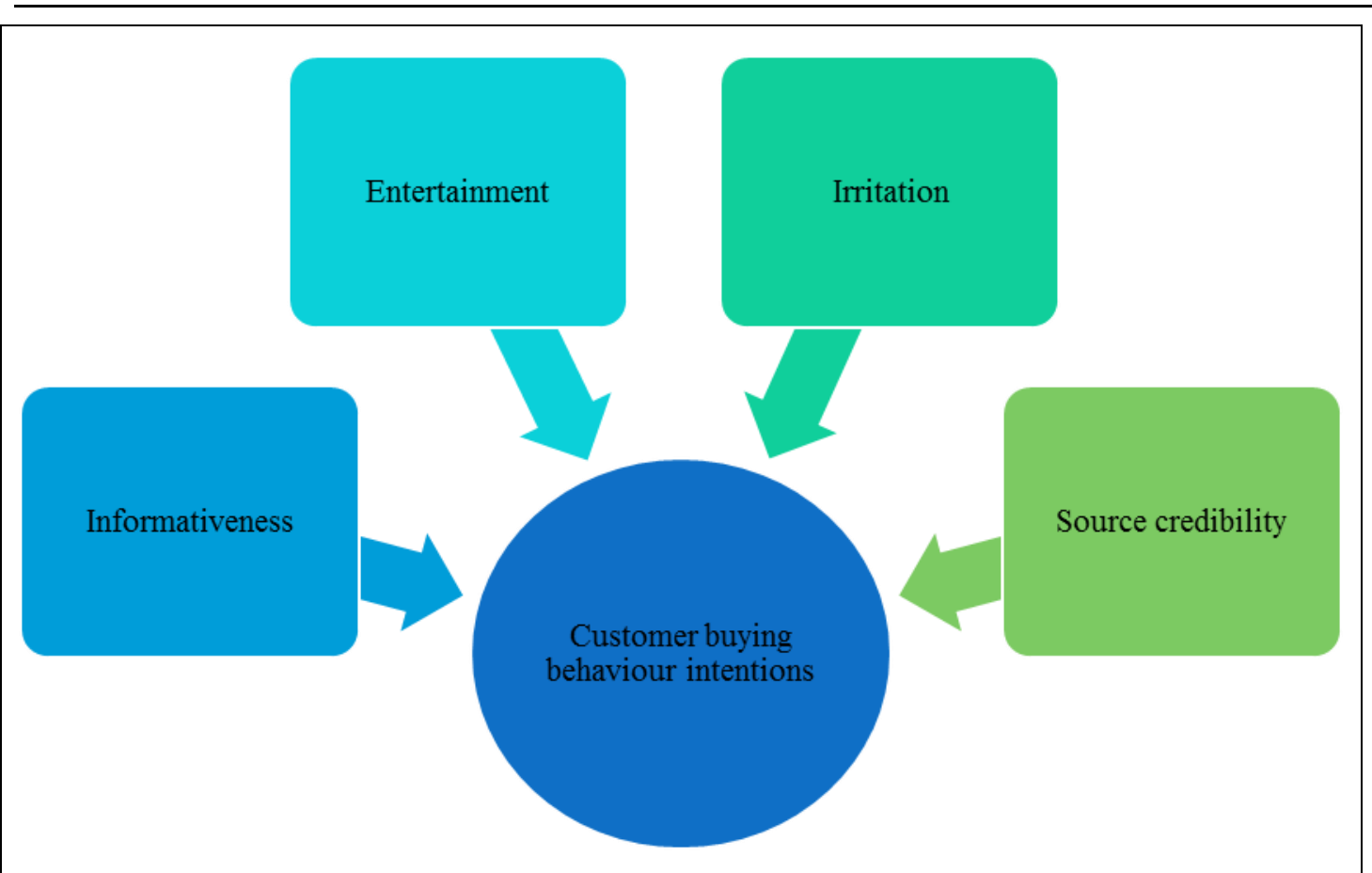

Figure 1. Conceptual theoretical model

Source: Researcher's own construct

\subsection{Study Hypotheses}

$\mathrm{H}_{1}$ : There is a positive relationship between informativeness and customer buying behavioural intentions.

$\mathrm{H}_{2}$ : There is a positive relationship between entertainment and customer buying behavioural intentions.

H3: $\quad$ There is a positive relationship between irritation and customer buying behavioural intentions.

H4: There is a positive relationship between source credibility and customer buying behavioural intentions.

\section{Research Methodology}

Since the study focused on understanding the influence of viral marketing strategies on customers' buying behavioral intentions at a retail outlet in Johannesburg with the use of a viral marketing strategy conceptual framework developed from literature, a descriptive case study design utilising the quantitative methodology was applied (Zernigah \& Sohail, 2012).

\subsection{Data Collection}

An adapted instrument, as developed by Zernigah and Sohail (2012) was used to collect data. The self-completion questionnaire was administered to a sample of 172 customers at a retail store in Johannesburg. Before carrying out the research, a pilot study was carried out with 10 
customers at the store to assess if questions were clear and understandable. Since permission to conduct the study was granted, research assistants assisted by distributing questionnaires at the store. Collection boxes were placed at the entrance of the store so that customers could deposit the completed questionnaires.

\subsection{Sampling}

Data was collected from the retail store in Johannesburg. The retail store enjoyed a total approximate of 1.2 million customers who walk in every month. As such, a sample of at least 172 customers participated in the study. Raosoft was utilised to determine the minimum sample size so as to maintain at least a 5 per cent margin of error and 95 per cent confidence interval (Raosoft, 2014). Similarly to previous similar studies (e.g. Zernigah \& Sohail, 2012), the convenience sampling method envisaged, was deemed not to compromise the quality of research because the sample was comprised of homogenous elements of customers at one retail store (Calder, Phillips \& Tybout, 1981).

\subsection{Data Analysis}

SPSS v.24 was utilised to conduct descriptive and multivariate analyses including factor analysis, correlations, and regression analyses to assess customers' perception on viral marketing strategies and their relation to customer buying behavioural intentions, as well as testing the hypotheses.

\subsection{Validity and Reliability}

Although a previously validated and reliable data collection instrument was used (Evanschitzky, Baumgarth, Hubbard \& Armstrong, 2007), further tests of validity and reliability were conducted using Cronbach's alpha and factor analysis, respectively. The supervisor as well as the pilot study were also consulted for inputs and recommendations in order to verify and ensure that the questionnaire complied with the guidelines and ethical requirements of research.

\section{Results}

\subsection{Demographic Distribution}

Descriptive analysis was performed to obtain frequency distribution of demographic variables which were gender, age, level of education, occupation and level of income. The frequency and percentage distribution of the demographic characteristics are illustrated in Table 1.

Table 1. Demographic profile of respondents

\begin{tabular}{|l|l|c|c|}
\hline \multicolumn{2}{|c|}{ Demographic characteristics } & Frequency & Per cent \\
\hline Gender & & & \\
\hline & Male & 87 & 51 \\
\hline & Female & 85 & 49 \\
\hline Age & & & \\
\hline & $<18$ years & 19 & 11 \\
\hline & $18-24$ years & 79 & 46 \\
\hline
\end{tabular}




\begin{tabular}{|l|l|c|c|}
\hline & $25-30$ years & 39 & 23 \\
\hline & $31-35$ years & 16 & 9 \\
\hline & $36+$ years & 19 & 11 \\
\hline Level of education & < matric & 10 & 5 \\
\hline & Matric & 26 & 15 \\
\hline & $\begin{array}{l}\text { college / university } \\
\text { student }\end{array}$ & 80 & 47 \\
\hline & Diploma / degree & 35 & 21 \\
\hline & $\begin{array}{l}\text { Postgraduate } \\
\text { (honours/ } \\
\text { masters/PhD) }\end{array}$ & 21 & 12 \\
\hline
\end{tabular}

Of the 172 respondents, 51 per cent were male while 49 per cent were female. Thus, the majority of respondents in this study were male. Table 1. illustrates this distribution. As given in Table 1, only 11 per cent of respondents were below the age of 18 years old, while 46 per cent were between 18 and 24 years old, 23 percent were within 25 - 30 years old, while 9 percent were 31 - 35 years old and lastly, 11 per cent were of the age 36 years old and above. Statistics reflect that the majority of customers were within the age group 18 and 24 years.

With regard to the level of education, 5 per cent of the respondents were found to be possessing a qualification below matric level, 15 per cent had matric level, 47 per cent were enrolled at college or university, 21 percent were with either a diploma or degree, and 12 percent of respondents were found to be possessing a postgraduate qualification.

\subsection{Customers' Perception on Viral Marketing Strategies and Overall Buying Behavioural} Intentions

Table 2. presents findings relating to customers' perception on viral marketing strategies on each of the four dimensions, and overall buying behavioural intention. A five-point Likert scale with $1=$ 'Strongly agree' and $5=$ 'Strongly disagree' was used to measure each item relating to customers' perceptions of viral marketing strategies. Perceptions on each of the four dimensions were calculated as a summated average of the items used under each dimension. Customers' perception of viral marketing strategies was calculated as a summated average of all the items used under the dimension. It is important to note that in this study, a scale of 1.0 to 2.49 was used to indicate good perception on viral marketing strategies, while 2.51 to 5.0 indicated bad perception.

Table 2. Perceived viral marking strategies on all respondents - descriptive $(n=172)$.

\begin{tabular}{|c|l|c|c|}
\hline & Dimensions and items & Mean & $\begin{array}{c}\text { Standard } \\
\text { deviation }\end{array}$ \\
\hline & Informativeness & 3.03 & 1.24 \\
\hline I1 & Find email marketing messages of the store informative. & 3.27 & 1.25 \\
\hline
\end{tabular}




\begin{tabular}{|c|c|c|c|}
\hline I2 & $\begin{array}{l}\text { Marketing messages displayed on social networking sites for } \\
\text { the store are informative. }\end{array}$ & 2.69 & 1.18 \\
\hline $\mathrm{I} 3$ & Fan pages on social networking sites for store are informative. & 3.30 & 1.33 \\
\hline I4 & $\begin{array}{l}\text { SMS advertisements by the store provide useful information } \\
\text { about the products. }\end{array}$ & 2.92 & 1.13 \\
\hline I5 & $\begin{array}{l}\text { Internet blogs of the store are an important source of } \\
\text { information. }\end{array}$ & 9.97 & 1.34 \\
\hline & Entertainment & 2.83 & 1.15 \\
\hline $\mathrm{E} 1$ & $\begin{array}{l}\text { Find marketing messages received from store via e-mails } \\
\text { entertaining. }\end{array}$ & 2.80 & 1.26 \\
\hline $\mathrm{E} 2$ & $\begin{array}{l}\text { Joining fan pages of the store on social networking sites is } \\
\text { entertaining and exciting. }\end{array}$ & 2.60 & 1.16 \\
\hline E3 & $\begin{array}{l}\text { The element of humour and fun of the store makes SMS } \\
\text { advertisements entertaining. }\end{array}$ & 2.92 & 1.09 \\
\hline E4 & $\begin{array}{l}\text { I find blogs of the store entertaining as people share their } \\
\text { views about products and services that make them interesting } \\
\text { and worth reading. }\end{array}$ & 3.03 & 1.12 \\
\hline & Irritation & 2.66 & 1.19 \\
\hline IR1 & $\begin{array}{l}\text { E-mail marketing messages of the store are a source of } \\
\text { irritation. }\end{array}$ & 2.72 & 1.28 \\
\hline IR2 & $\begin{array}{l}\text { I believe that unsolicited e-mails from the store contain } \\
\text { viruses. }\end{array}$ & 2.80 & 1.15 \\
\hline IR3 & $\begin{array}{l}\text { Marketing messages on social media sites of the store are } \\
\text { irritating. }\end{array}$ & 2.34 & 1.22 \\
\hline
\end{tabular}




\begin{tabular}{|c|c|c|c|}
\hline IR4 & I delete SMS advertisements from the store without reading. & 2.87 & 1.21 \\
\hline IR5 & The store's SMS advertisements are annoying. & 2.30 & 1.23 \\
\hline IR6 & $\begin{array}{l}\text { I find blogs irritating as the information provided is } \\
\text { misleading and unreliable. }\end{array}$ & 2.97 & 1.09 \\
\hline & Source credibility & 3.19 & 1.17 \\
\hline $\mathrm{SC} 1$ & $\begin{array}{l}\text { I trust the information provided by marketers of the store } \\
\text { through e-mails. }\end{array}$ & 3.20 & .98 \\
\hline $\mathrm{SC} 2$ & Fan pages on social media sites of the store are trustworthy. & 3.48 & 1.30 \\
\hline $\mathrm{SC} 3$ & I trust the SMS advertisements received from the store. & 3.37 & 1.24 \\
\hline $\mathrm{SC} 4$ & I trust the information provided by bloggers of the store. & 2.72 & 1.17 \\
\hline & Overall buying behavioural intentions & 2.86 & 1.12 \\
\hline OBI1 & I will become part of viral campaigns of the store. & 2.95 & 1.17 \\
\hline OBI2 & $\begin{array}{l}\text { I consider viral marketing of the store as a useful marketing } \\
\text { tool for creating brand awareness. }\end{array}$ & 2.79 & 1.13 \\
\hline OBI3 & $\begin{array}{l}\text { I would help the store to spread viral messages to my friends } \\
\text { and relatives so that they buy more from the store. }\end{array}$ & 2.97 & 1.10 \\
\hline OBI4 & $\begin{array}{l}\text { Viral marketing of the store convinces me to buy more of its } \\
\text { products. }\end{array}$ & 2.76 & 1.08 \\
\hline
\end{tabular}

At the subdimensional level, Table 2. reflects that four variables representing viral marketing strategies that are informativeness (I), entertainment (E), irritation (IR) and source credibility (SC). The viral marketing strategies were perceived as bad. This was deduced from the mean values $(I=3.03),(E=2.83),(I R=2.66)$ and $(S C=3.19)$ that were above the mean value 2.5. Results show that viral marketing strategies used at the retail outlet were not regarded appropriate as evidenced by the perception of customers that was unfavourable. 
9.3 Validity and Reliability Analysis

\subsubsection{Validity}

In order to ensure the validity and reliability of the used research instrument (questionnaire), confirmatory factor analysis and reliability tests were conducted using SPSS version 24 . All items in the instrument were measured and had a value more than 0.5 , demonstrating evidence that the tool utilised was valid. The results of the analysis are shown in Table 3.

Table 3. Results of validity and reliability analysis on 23 viral marketing strategies items

\begin{tabular}{|c|c|c|c|c|c|}
\hline \multicolumn{6}{|c|}{ Factors } \\
\hline & 1 & 2 & 3 & 4 & 5 \\
\hline I1 & .63 & & & & \\
\hline I2 & .59 & & & & \\
\hline I3 & .62 & & & & \\
\hline I4 & .64 & & & & \\
\hline I5 & .66 & & & & \\
\hline E1 & & .62 & & & \\
\hline E2 & & .60 & & & \\
\hline E3 & & .59 & & & \\
\hline E4 & & .54 & & & \\
\hline IR1 & & & .63 & & \\
\hline IR2 & & & .66 & & \\
\hline IR3 & & & .62 & & \\
\hline IR4 & & & .50 & & \\
\hline
\end{tabular}




\begin{tabular}{|c|c|c|c|c|c|}
\hline IR5 & & & .54 & & \\
\hline IR6 & & & .50 & & \\
\hline SC1 & & & & .53 & \\
\hline $\mathrm{SC} 2$ & & & & .68 & \\
\hline $\mathrm{SC} 3$ & & & & .61 & \\
\hline $\mathrm{SC} 4$ & & & & .64 & \\
\hline AVM1 & & & & & .59 \\
\hline AVM2 & & & & & .64 \\
\hline AVM3 & & & & & .61 \\
\hline AVM4 & & & & & .60 \\
\hline$\alpha$ & .78 & .72 & .71 & .75 & .77 \\
\hline
\end{tabular}

After testing the validity of the instrument, a reliability test followed through the use of Cronbach's Alpha coefficient. All items were above 0.7, a minimum threshold recommended by Field (2009). After having established both the construct validity and reliability of the questionnaire, it was concluded that the items used to measure variables representing viral marketing strategies and buying behavioural intention constructs, were reliable. Thus, researchers proceeded with further analysis.

\subsection{The Correlation and Regression Analysis}

Correlation and regression are most suitable for a study which seeks to test a relationship between variables for such as this current study that tested the relationship between viral marketing strategies and buying behavioural intention. Correlation and regression are also usually used for a larger sample size, for example 172 used in this study. A Likert scale was also used for responses, which is another required condition for correlation and regression analyses utilised to test the relationship in this study. To test the hypothesised relationships given in Figure 2.1 in Chapter 2, thus between viral marketing strategies (informativeness, entertainment, irritation and source credibility) and buying behavioural intention, correlation and regression analyses were performed. 


\section{Ml Macrothink}

Note that overall buying behavioural intentions as a dependent variable, were measured as a summated average of four items, namely 'I will become part of viral campaigns of the store', 'I consider viral marketing of the store as a useful marketing tool for creating brand awareness', 'I would help the store to spread viral messages to my friends and relatives so that they buy more from the store', and 'Viral marketing of the store convinces me to buy more of its products'. A five-point Likert scale with $1=$ 'Strongly agree' and $5=$ 'Strongly disagree' was also used to measure items of buying behavioural intentions.

9.4.1 Correlation Analysis among Strategies for Viral Marketing and Buying Behavioural Intentions

Results on the correlation analysis that was used to test the strength of the relationship between viral marketing strategies (independent variables) and buying behavioural intentions (dependent variable), are shown in Table 4. Also note that values represented as (r) Pearson correlation indicates the strength of the relationship between variables, (0) standing for no relationship, (0.1 to 0.4$)$ for weak positive relationship, (0.5) standing for moderate relationship, and (0.6 to 1 ) standing for a strong positive relationship. The-p value indicates the probability that r-value is only seen by chance, hence a lower p-value means that the r-value is not seen by chance.

Table 4. Correlation analysis

\begin{tabular}{|c|c|c|}
\hline Dimensions & & $\begin{array}{c}\text { Overall buying behavioural } \\
\text { intentions }\end{array}$ \\
\hline \multirow[t]{3}{*}{ Informativeness } & $\mathrm{r}$ & 0.56 \\
\hline & $\mathrm{p}$ & $0.000^{*}$ \\
\hline & $\mathrm{N}$ & 172 \\
\hline \multirow[t]{3}{*}{ Entertainment } & $\mathrm{r}$ & 0.47 \\
\hline & $\mathrm{p}$ & $0.0003 *$ \\
\hline & $\mathrm{N}$ & 172 \\
\hline \multirow[t]{3}{*}{ Irritation } & $\mathrm{r}$ & 0.54 \\
\hline & $\mathrm{p}$ & $0.000^{*}$ \\
\hline & $\mathrm{N}$ & 172 \\
\hline \multirow[t]{3}{*}{ Source credibility } & $\mathrm{r}$ & 0.58 \\
\hline & $\mathrm{p}$ & $0.000^{*}$ \\
\hline & $\mathrm{N}$ & 172 \\
\hline
\end{tabular}

$\mathrm{P}<0.001^{*}$

Correlation results shown in Table 4. shows that all viral marketing strategies variables (informativeness, entertainment, irritation and source credibility) were positively related to overall buying behavioural intentions. This is evidenced by positive $\mathrm{p}$-values of all the factors ranging from 0.4 to 0.6 , as well as the p-value that is below 0.001 . The next section presents 
results of the regression analysis that was conducted to test the hypothesized relationships in this study.

\subsubsection{Regression Analysis}

Given that this study had four hypotheses and a Likert scale research instrument with responses in continuous form, conducting regression analyses was necessary. Table 5 presents the results of regression analysis and the four hypotheses are tested as follows:

Following the results from regression analyses $(\mathrm{p}<0.001, \mathrm{R}=0.56)$, Hypothesis $\mathrm{H} 1$ that states that there is a positive relationship between informativeness and customer buying behavioural intention, is accepted at 0.000 significance level. This implies that an increase in informativeness of viral marketing strategies, such as ensuring that information provided is relevant and useful to the receiver, leads to increased consumer buying behavioural intention. In line with this finding, Zernigah and Sohail (2012)'s study also found informativeness to be the most important aspect in viral marketing.

Following the results from regression analyses $(\mathrm{p}<0.001, \mathrm{R}=0.47)$, Hypothesis $\mathrm{H} 2$ that states that there is a positive relationship between entertainment and customer buying behavioural intention, is accepted at 0.000 significance level. This also means that an increase in the level of entertainment in viral marketing strategies utilised, for example, use of humour within the messages leads to an increase in the level of customer buying behavioural intentions. In support of this finding, Muzaffar and Kamran (2011), Shashikala and Mahapatro (2015) and Reyck and Degraeve (2003) found entertainment to be the most important aspect that leads to positive customer attitude towards viral marketing.

Following the results from regression analyses $(\mathrm{p}<0.001, \mathrm{R}=0.54)$, Hypothesis $\mathrm{H} 3$ that states that there is a positive relationship between irritation and customer buying behavioural intention is accepted at 0.000 significance level. This implies that irritation has an impact towards customers' buying behavioural intentions. Blanco et al. (2010) and Shashikala and Mahapatro (2015) found irritation to be positively related to customer buying behavioural intentions.

Following the results from regression analyses $(\mathrm{p}<0.001, \mathrm{R}=0.58)$, Hypothesis $\mathrm{H} 4$ that states that there is a positive relationship between source credibility and customer buying behavioural intention, is accepted at 0.000 significance level. This implies that an increase in source credibility leads to an increase in buying behavioural intentions. Zernigah and Sohail (2012)'s study also found source credibility to be the most important aspect in viral marketing.

Table 5. Regression analysis

Dependent variable: Overall buying behavioural intention

\begin{tabular}{|c|c|c|c|c|c|}
\hline & SEB & $\boldsymbol{\beta}$ & R & Sig & Hypothesis \\
\hline (Constant) & 0.71 & & & & \\
Perceived informativeness & 0.07 & 0.56 & 0.56 & 0.000 & Accept H1 \\
\hline
\end{tabular}




\begin{tabular}{|c|c|c|c|c|c|}
\hline (Constant) & 0.45 & & & & \\
\hline Perceived entertainment & 0.05 & 0.47 & 0.47 & 0.000 & Accept H2 \\
\hline (Constant) & 0.63 & & & & \\
\hline Perceived irritation & 0.08 & 0.54 & 0.54 & 0.000 & Accept H3 \\
\hline (Constant) & 0.74 & & & & \\
\hline $\begin{array}{c}\text { Perceived source } \\
\text { credibility }\end{array}$ & 0.06 & 0.58 & 0.58 & 0.000 & Accept H4 \\
\hline
\end{tabular}

$\mathrm{P}<0.001^{*}$

The regression coefficients are illustrated in Table 5. SEB is the standard error coefficient, and $\mathrm{R}$ is the Pearson coefficient ( $\mathrm{r}$ ) that shows the direction and strength of a relation either positive or negative. Sig ( $p$ value) is the probability that $R$ is seen only by chance. The lower the significant value, the higher the chances that $\mathrm{r}$-value will always be seen, hence the reliability of results.

\section{Summary of the Findings}

Findings from descriptive analysis showed that perceptions of customers towards viral marketing strategies used by the retail store in Johannesburg, were negative. Correlation and regression analyses showed a positive relationship between informativeness, entertainment, irritation, source credibility and customer buying behavioural intentions. Table 6 summarises the hypotheses and major results.

Table 6. A summary of the hypotheses and major results

\begin{tabular}{|c|l|l|}
\hline & \multicolumn{1}{|c|}{ Hypotheses } & \multicolumn{1}{c|}{ Results } \\
\hline $\mathrm{H}_{1}:$ & $\begin{array}{l}\text { There is a positive relationship between } \\
\text { informativeness and customer buying behavioural } \\
\text { intentions. }\end{array}$ & $\begin{array}{l}\text { Accept }(\mathrm{p}<0.001, \mathrm{r}=0.56, \beta \\
=0.56)\end{array}$ \\
\hline $\mathrm{H}_{2}:$ & $\begin{array}{l}\text { There is a positive relationship between entertainment } \\
\text { and customer buying behavioural intentions. }\end{array}$ & $\begin{array}{l}\text { Accept }(\mathrm{p}<0.001, \mathrm{r}=0.47, \beta \\
=0.47)\end{array}$ \\
\hline $\mathrm{H}_{3}:$ & $\begin{array}{l}\text { There is a positive relationship between irritation and } \\
\text { customer buying behavioural intentions. }\end{array}$ & $\begin{array}{l}\text { Accept }(\mathrm{p}<0.001, \mathrm{r}=0.54, \beta= \\
0.54)\end{array}$ \\
\hline $\mathrm{H}_{4}:$ & $\begin{array}{l}\text { There is a positive relationship between source } \\
\text { credibility and customer buying behavioural } \\
\text { intentions. }\end{array}$ & $\begin{array}{l}\text { Accept }(\mathrm{p}<0.001, \mathrm{r}=0.58, \beta= \\
0.58)\end{array}$ \\
\hline
\end{tabular}

At this point, the research question which states: "To what extent do the perceptions of viral marketing strategies influence buying behavioural intentions among customers at the retail store in Johannesburg?" can also be answered. Viral marketing strategies affect customer buying behavioural intentions to a great extent as given by the hypotheses in Table 6 . 


\section{Implications for Practice}

Following the findings of this study that showed that customers had a negative perception towards viral marketing strategies utilised by the retail store in Johannesburg, recommendations are given in this section. The recommendations are given in order to assist management in improving their strategies. These are given as follows:

It is important for the management of the retail store to ensure that messages sent through viral marketing, are informative. This has to be placed on e-mail and social site (i.e. Facebook, Twitter, Wechat) messages sent to the customers. The information sent to customers about products and services needs to be useful to the customers.

It is important for management to ensure that messages that are sent to customers are entertaining. This will help to retain consumer interest. Hence, it is important to ensure that messages sent via e-mail or social sites have humour and fun, as it will lead to good circulation.

Management needs to ensure that messages that are sent to customers, are free from irritation. Thus messages need to be free from viruses. The messages should not be annoying. It also has to be ensured that the message is not misleading and unreliable, as customers get irritated by such forms of messages.

It is important that the retail store works on its credibility. The credibility of the store can be achieved through participation in social responsibility programmes, for example, sponsoring of charitable events and sports. This will help to build the name of the organisation such that the receiver of the message realises the worthiness of the sender.

This section gives recommendations to management to ensure that viral marketing programmes of the retail store are correct. In the next section limitations of this study are given.

\section{Limitations of the Study}

This study provided four limitations. Its first limitation is that the study concentrated on a limited sample of customers of the retail store in Johannesburg. Hence, its findings cannot be generalised to all the customers of the retail outlets in South Africa. The second limitation was that data was collected over a short duration of time, thus within a month, resulting in the study to be cross-sectional. This gave an indication of customers' perceptions within one month, excluding a possibility in change of opinions that can take place if the duration was prolonged.

It can also be noted that the study was conducted using quantitative research methods. Thus the questionnaire could not offer respondents a chance to express their opinions, since there were no open-ended questions. Lastly, the study only tested four factors (informativeness, entertainment, irritation and source credibility) as factors representing viral marketing strategies. There are other factors that could have been considered as strategies for viral marketing. 


\section{Direction for Future Research}

Future research can replicate the study by collecting data from more customers in different towns and provinces of South Africa. A further study can also be carried out from other retail stores different from the one tested in this study. A study that compares viral marketing strategies used by different stores can be desirable as well. Future research can be carried out over an extended period, for example 6 months, to make it longitudinal and determine if there will be changes of perceptions over time on the viral marketing strategies utilised. Future studies can be carried out making use of qualitative research methods. There are other factors that might be important to consider as strategies of viral marketing. All these are opportunities for further studies.

\section{Conclusion}

The objective of this study was to assess customers' perception of viral marketing strategies and to investigate how these strategies influence buying behavioural intentions. Extant literature showed gaps within the body of knowledge, and these were concerned with the use of viral marketing strategies within a retail store. The research question, objectives and several hypotheses were formulated and presented. The research methodology used to operationalise the study has been discussed. Data analyses have been presented, while findings and recommendations are discussed. The objective of the study was to investigate and attempt to answer the question: "To what extent do the perceptions of viral marketing strategies influence buying behavioral intentions among customers at the retail store in Johannesburg?" It is therefore concluded that customers perceived the viral marketing strategies (informativeness, entertainment, irritation and source credibility) utilised by the retail store to be poor. Findings also indicate the viral marketing strategies are to a great extent positively correlated to buying behavioural intentions.

\section{Acknowledgements}

Special thanks go to the CTI Education Group and Pearson Institute of Higher Education (Bedfordview campus), South Africa for providing the authors with an opportunity to conduct this study, as well as supporting its publication.

\section{References}

Akrimi, Y., \& Khemakhem, R. (2012). What drive consumers to spread the word in social media? Journal of Marketing Research \& Case Studies, 1-14. https://doi.org/10.5171/2012.969979

Bampo, M., Ewing, M. T., Mather, D. R., Stewart, D., \& Wallace, M. (2008). The effects of the social structure of digital networks on viral marketing performance. Information Systems Research, 19(3), 273-290. https://doi.org/10.1287/isre.1070.0152 
Blanco, C. F., Blasco, M. G., \& Azorin, I. I. (2010). Entertainment and informativeness as Precursory Factors of Successful Mobile Advertising Messages. Communications of the IBIMA, 1-11. https://doi.org/10.5171/2010.130147

Business Tech. (2015). South African online shopping only 1\% of retail sales. [Online] Available from:

http://businesstech.co.za/news/internet/86720/sa-online-shopping-only-1-of-retail-sales/ (Accessed 09/09/2016).

Calder, B. J., Phillips, L. W., \& Tybout, A. M. (1981). Designing research for application. The Journal of Consumer Research, 8(2), 197-207. https://doi.org/10.1086/208856

Chiu, H. C., Hsieh, Y. C., Kao, Y. H., \& Lee, M. (2007). The determinants of email receivers' disseminating behaviors on the Internet. Journal of Advertising Research, 47(4), 524-34. https://doi.org/10.2501/S0021849907070547

Dawar, S., \& Dawar, P. (2015). Viral Marketing: A concept of paradigm shift in marketing. International Journal of Management and Social Sciences Research, 4(5), 2319-4421.

Eckler, P., \& Bolls, P. (2011). Spreading the virus: emotional tone of viral advertising and its effect on forwarding intentions and attitudes. Journal of Interactive Advertising, 11(2), 1-11. http://dx.doi.org/10.3916/C43-2014-20

Evanschitzky, H., Baumgarth, C., Hubbard, R., \& Armstrong, J. S. (2007). Replication research's disturbing agenda. Journal of Business Research, 60(2007), 411-415. https://doi.org/10.1016/j.jbusres.2006.12.003

Fagerstrom, A., \& Ghinea, G. (2010). Web 2.0's marketing impact on low-involvement consumers. Journal of Interactive Advertising, 10(2), 67-71.

Field, A. (2009). Discovering statistics using SPSS. 3rd ed. Thousand Oaks, CA: Sage.

Gangadharbatla, H. (2008). Facebook me: Collective self-esteem, need to belong and Internet self-efficacy as predictors of the iGeneration's attitude towards social networking sites. Journal of Interactive Advertising, $\quad 8(2), \quad$ 5-15. https://doi.org/10.1080/15252019.2008.10722138

Ghane, N., Shokrizadeh, H., Omidvar, M., \& Comyab, H. (2014). Investigating the effective factors on electronic trade by viral marketing. Management Science Letters, 4(4), 713-720. https://doi.org/10.1287/opre.51.4.509.16104

Goldsmith, R. E., \& Horowitz, D. (2004). Measuring motivations for online opinion seeking. Journal of Interactive Advertising, 6(2), 3-14.

Haghirian, P., Madlberger, M., \& Tanuskova, A. (2005). Increasing Advertising Value of Mobile Marketing- An Empirical Study of Antecedents in: Proceedings of 38th Hawaii International Conference on System Sciences, Big Island, HI, USA, January 3-6. 
Muzaffar, F., \& Kamran, S. (2011). SMS Advertising: Youth Attitude towards Perceived Informativeness, Irritation and Credibility. Interdisciplinary Journal of Contemporary Research in Business, 3(1), 230-245.

Palka, W., Pousttchi, K., \& Wiedemann, D. G. (2009). Mobile Word-of-Mouth - A Grounded theory of Mobile Viral Marketing. Journal of Information Technology, 24(2), 172-185. http://dx.doi.org/10.1080/15252019.2013.826553

Pelău, C., \& Zegreanu, P. (2010). Mobile marketing- The marketing for the next generation. Management \& Marketing, 5(2), 101-116.

Raosoft. (2014). Sample size calculator. [Online] Available from: http://www.raosoft.com/samplesize.html [Accessed 10/09/2016].

Reyck, B. D., \& Degraeve, Z. (2003). Broadcast Scheduling for Mobile Advertising. Operations Research, 51(4), 509-517. https://doi.org/10.1287/opre.51.4.509.16104

Robbins, S. P., Judge, T. A., Odendaal, A., \& Roodt, G. (2016). Organisational Behaviour: Global and South African perspectives (3rd Ed). Cape Town: Pearson.

Saadeghvaziri, F., \& Hosseini, H. K. (2011). Mobile advertising: an investigation of factors creating positive attitude in Iranian customers. African Journal of Business Management, 5(2), 394-404. https://doi.org/10.1016/j.dss.2008.06.007

Shashikala, R., \& Mahapatro, P. (2015). A Study on Analysing the Effectiveness of Viral Marketing in the Era of Mobile Messenger Apps with special reference to WhatsApp. International Journal of Research in Management, Social Sciences \& Technology, 10(10), 2320-2793.

Tsang, M. M., Ho, S. C., \& Liang, T. P. (2004). Consumer Attitudes toward Mobile Advertising: An Empirical Study. International Journal of Electronic Commerce, 8(3), $65-78$.

Woerndl, M., Papagiannidis, S., Bourlakis, M., \& Li, F. (2008). Internet-Induced Marketing Techniques: Critical Factors in Viral Marketing Campaigns. International Journal of Business Science and Applied Management, 3(1), 33 - 45.

World Wide Worx. (2016). South Africa Social Media Landscape (2016). Executive summary Instagram and Facebook make biggest waves. [Online] Available from: http://www.worldwideworx.com [Accessed 21/09/2016].

Zernigah, K. I., \& Sohail, K. (2012). Consumers' attitude towards viral marketing in Pakistan. Management \& Marketing Challenges for the Knowledge Society, 7(4), 645 - 662.

\section{Appendix 1}

Dear Respondent 
Thank you for participating in this research. This questionnaire is part of a study aimed at assessing customers' perceptions and attitudes towards viral marketing strategies used at the retail store in Johannesburg. Please note, this questionnaire was adapted from Zernigah and Sohail (2012) and adjusted to suit this present study. Please take note that your name is not required nor is it requested, hence confidentiality is assured. Also note that your decision to take part is entirely voluntary. The questionnaire will only take 5-10 minutes of your time. The answers from your questionnaire and others will be used as the main data set for the research project.

\section{$\underline{\text { General Instructions }}$}

The following instructions and conditions must be understood by all respondents:

a) Specific instructions for each section are provided;

b) When evaluating the questions, please provide the answer from your own perspective;

c) Please complete all questions, do not leave any unanswered questions;

d) Please make use of the scale proved to you for each of the questions;

e) Please return the completed questionnaire by depositing it in the box provided by a research assistant.

Your cooperation will be much appreciated.

Thank you SECTION A: DEMOGRAPHICS

1. What is your gender?

\begin{tabular}{|l|c|}
\hline Male & 1 \\
\hline Female & 2 \\
\hline
\end{tabular}

2. What is your age in years?

\begin{tabular}{|l|l|}
\hline$<18$ years & 1 \\
\hline $18-24$ years & 2 \\
\hline $25-30$ years & 3 \\
\hline $31-35$ years & 4 \\
\hline $36+$ years & 5 \\
\hline
\end{tabular}

3. What is your level of education? 


\begin{tabular}{|l|c|}
\hline Below grade 12 (Matric) & 1 \\
\hline Matric (Grade 12) & 2 \\
\hline Currently at college or university & 3 \\
\hline $\begin{array}{l}\text { Diploma / Degree } \\
\text { Postgraduate (Honours , Masters, } \\
\text { Doctorate) }\end{array}$ & 4 \\
\hline
\end{tabular}

4. What is your occupation?

\begin{tabular}{|l|c|}
\hline Student & 1 \\
\hline Professional (Teacher, Doctor, etc) & 2 \\
\hline IT related & 3 \\
\hline Non-IT & 4 \\
\hline Administrator & 5 \\
\hline Manager & 6 \\
\hline Other & 7 \\
\hline
\end{tabular}

5. What is your net income per month?

\begin{tabular}{|l|c|}
\hline$<$ R5 000 & 1 \\
\hline R5 000- R10 000 & 2 \\
\hline R 10 001- R20 000 & 3 \\
\hline R20 001+ & 4 \\
\hline
\end{tabular}




\section{SECTION B: OPINIONS SOUGHT}

In this section, please indicate the extent to which you agree or disagree with each of the following statements. You may indicate your answer by placing a cross $(\mathrm{x})$ in your selected response, using the scale: $(1)=$ Strongly Agree; $(2)=$ Agree; $(3)=$ Neutral; $(4)=$ Disagree; $(5)=$ Strongly Disagree

\begin{tabular}{|c|c|c|c|c|c|c|}
\hline \multicolumn{2}{|c|}{ Informativeness } & Strongly & Agree & Neutral & Disagree & Strongly \\
\hline I1 & $\begin{array}{l}\text { I find e-mail marketing messages of the store } \\
\text { informative. }\end{array}$ & 1 & 2 & 3 & 4 & 5 \\
\hline I2 & $\begin{array}{l}\text { Marketing messages displayed on social } \\
\text { networking sites (such as Facebook, Twitter, } \\
\text { Orkut) for the store are informative. }\end{array}$ & 1 & 2 & 3 & 4 & 5 \\
\hline $\mathbf{I 3}$ & $\begin{array}{l}\text { Fan pages on social networking sites for the } \\
\text { store are informative. }\end{array}$ & 1 & 2 & 3 & 4 & 5 \\
\hline I4 & $\begin{array}{l}\text { SMS advertisements by the store provide } \\
\text { useful information about products and } \\
\text { services. }\end{array}$ & 1 & 2 & 3 & 4 & 5 \\
\hline I5 & $\begin{array}{l}\text { Internet Blogs of the store are an important } \\
\text { source of information. }\end{array}$ & 1 & 2 & 3 & 4 & 5 \\
\hline
\end{tabular}

\section{Entertainment}

Strongly

Agree

(1)
(2)

(3)

\section{Neutral Disagree \\ Strongly \\ Disagree}

(5) 


\begin{tabular}{|c|c|c|c|c|c|c|}
\hline E1 & $\begin{array}{l}\text { I find marketing messages received from } \\
\text { the store via e-mails entertaining. }\end{array}$ & 1 & 2 & 3 & 4 & 5 \\
\hline E2 & $\begin{array}{l}\text { Joining fan pages of the store on social } \\
\text { networking sites is entertaining and } \\
\text { exciting. }\end{array}$ & 1 & 2 & 3 & 4 & 5 \\
\hline E3 & $\begin{array}{l}\text { The element of humour and fun of the } \\
\text { store makes SMS advertisements } \\
\text { entertaining. }\end{array}$ & 1 & 2 & 3 & 4 & 5 \\
\hline E4 & $\begin{array}{l}\text { I find the blogs of the store entertaining as } \\
\text { people share their views about products } \\
\text { and services that make them interesting } \\
\text { and worth reading. }\end{array}$ & 1 & 2 & 3 & 4 & 5 \\
\hline
\end{tabular}

\begin{tabular}{|c|c|c|c|c|c|c|}
\hline \multicolumn{2}{|c|}{ Irritation } & & & Neutral & Disagree & \\
\hline IR1 & $\begin{array}{l}\text { E-mail marketing messages of the store are } \\
\text { a source of irritation. }\end{array}$ & 1 & 2 & 3 & 4 & 5 \\
\hline IR2 & $\begin{array}{l}\text { I believe that unsolicited e-mails from the } \\
\text { store contain viruses. }\end{array}$ & 1 & 2 & 3 & 4 & 5 \\
\hline IR3 & $\begin{array}{l}\text { Marketing messages on social media sites } \\
\text { of the store are irritating. }\end{array}$ & 1 & 2 & 3 & 4 & 5 \\
\hline IR4 & $\begin{array}{l}\text { I delete SMS advertisements from the store } \\
\text { without reading. }\end{array}$ & 1 & 2 & 3 & 4 & 5 \\
\hline IR5 & $\begin{array}{l}\text { The store's SMS advertisements are } \\
\text { annoying. }\end{array}$ & 1 & 2 & 3 & 4 & 5 \\
\hline IR6 & $\begin{array}{l}\text { I find blogs irritating as the information } \\
\text { provided is misleading and unreliable. }\end{array}$ & 1 & 2 & 3 & 4 & 5 \\
\hline
\end{tabular}




\begin{tabular}{|l|l|c|c|c|c|c|}
\hline \multicolumn{2}{|l|}{ Source credibility } & $\begin{array}{c}\text { Strongly } \\
\text { Agree } \\
(\mathbf{1})\end{array}$ & Agree & Neutral & Disagree & $\begin{array}{c}\text { Strongly } \\
\text { Disagree } \\
\text { (5) }\end{array}$ \\
\hline SC1 & $\begin{array}{l}\text { I trust the information provided by } \\
\text { marketers of the store through e-mails. }\end{array}$ & 1 & 2 & 3 & 4 & 5 \\
\hline SC2 & $\begin{array}{l}\text { Fan pages on social media sites of the } \\
\text { store are trustworthy. }\end{array}$ & 1 & 2 & 3 & 4 & 5 \\
\hline SC3 & $\begin{array}{l}\text { I trust SMS advertisements received } \\
\text { from the store. }\end{array}$ & 1 & 2 & 3 & 4 & 5 \\
\hline SC4 & $\begin{array}{l}\text { I trust the information provided by } \\
\text { bloggers of the store. }\end{array}$ & 1 & 2 & 3 & 4 & 5 \\
\hline
\end{tabular}

\begin{tabular}{|l|l|c|c|c|c|c|}
\hline Overall buying intentions & $\begin{array}{c}\text { Strongly } \\
\text { Agree } \\
\text { (1) }\end{array}$ & Agree & Neutral & Disagree & $\begin{array}{c}\text { Strongly } \\
\text { Disagree } \\
\text { (5) }\end{array}$ \\
\hline OBI1 & $\begin{array}{l}\text { I will become part of viral campaigns } \\
\text { of the store. }\end{array}$ & 1 & 2 & 3 & 4 & 5 \\
\hline OBI2 & $\begin{array}{l}\text { I consider viral marketing of the store } \\
\text { as a useful marketing tool for creating } \\
\text { brand awareness. }\end{array}$ & 1 & 2 & 3 & 4 & 5 \\
\hline OBI3 & $\begin{array}{l}\text { I would help the store to spread viral } \\
\text { messages to my friends and relatives } \\
\text { so that they buy more from the store. }\end{array}$ & 1 & 2 & 3 & 4 & 5 \\
\hline OBI4 & $\begin{array}{l}\text { Viral marketing of the store convinces } \\
\text { me to buy more of its products. }\end{array}$ & 1 & 2 & 3 & 4 & 5 \\
\hline
\end{tabular}

\section{Copyright Disclaimer}

Copyright for this article is retained by the author(s), with first publication rights granted to the journal.

This is an open-access article distributed under the terms and conditions of the Creative Commons Attribution license (http://creativecommons.org/licenses/by/3.0/). 